\title{
Voice Onset Time of Children with Functional Articulation Disorders
}

\author{
Jongsuk Park ${ }^{\mathrm{a}, \mathrm{b}}$, Youngmee Lee \\ ${ }^{a}$ Department of Speech-Language Therapy E Aural Rehabilitation, Graduate School of Health and Welfare, Woosong University, Daejeon, Korea \\ ${ }^{b}$ Dong-A Auditory Rehabilitation Center, Busan, Korea \\ 'Department of Communication Disorders, Tongmyong University, Busan, Korea
}

\author{
Correspondence: Youngmee Lee, $\mathrm{PhD}$ \\ Department of Communication Disorders, \\ Tongmyong University, 428 Sinseon-ro, Nam-gu, \\ Busan 48520, Korea \\ Tel: +82-51-629-2135 \\ Fax: +82-51-629-2019 \\ E-mail:ymlee@tu.ac.kr; ymlee3060@gmail.com
}

Received: April 5, 2016

Revised: May 16, 2016

Accepted: May 30, 2016

\begin{abstract}
Objectives: Various factors associated with the speech motor control skills in children with functional articulation disorders (FAD) have been studied. Voice onset time (VOT) is a temporal acoustic parameter that reflects motor speech coordination skills. In this study, we investigated the VOT of the VCV syllables which contain plosives classified according to the place of articulation and phonation types for children with FAD in comparison with children with typical speech development (TSD). Methods: Fifteen children with FAD were included in this study, ranging from 3 years and 11 months to 8 years and 11 months. Fifteen children with TSD as a control group were matched to the children with FAD on the basis of chronological age within \pm 3 months. All children produced plosives in isolation and VOTs were measured by the CSL program. A three-way mixed design was used with the groups as a between-subject factor, the place of articulation and phonation types as withinsubject factors. Results: There were not significant differences in VOTs between children with FAD and children with TSD. There were significant differences in VOT among the place of articulation, showing that children had the longest VOT for velars (all $p<.001$ ). In addition, the VOTs for aspirated consonants were longer than other consonants, and the differences were significant among three phonation types (all $p<.001$ ). Conclusion: The current results suggested that children with FAD can control the speech timing between the structures of the larynx and the oral cavity at the same levels of children with TSD.
\end{abstract}

Keywords: Voice onset time, Functional articulation disorders, Place of articulation, Phonation type
기능적 조음음운장애(functional articulation disorders)는 구조 적·신경학적 문제없이 말소리 산출에 어려움을 보이는 말장애를 말 한다(Bauman-Waengler, 2012). Bernthal, Bankson과 Flipsen (2012) 은 기능적 조음음운장애가 말기제의 뚜렷한 손상 없이 나타난다 는 점에 초점을 두고 원인불명의 조음장애라고 지칭하기도 하였다. 언어치료 현장에서 표준화된 조음음운검사로 산출되는 자음정확 도(percentage of consonants correct, PCC)와 조음기관의 구조 및 기능에 관한 선별검사 결과를 토대로 말소리 문제의 원인을 파악하 고 기능적 조음음운장애를 진단하고 있다(Kim \& Shin, 2007; Song, 2008). 기능적 조음음운장애 아동의 말소리 오류와 관련된 요인을 파악하기 위해서 운동통제 모델(motor control model)을 근거로
선행연구가 진행되었으며, 기능적 조음음운장애의 말소리 오류를 말 운동통제능력 저하에 초점을 두어서 설명하고자 하였다.

운동통제 모델에서는 감각운동과정(sensory motor process)에 서 말 산출을 위해 필요한 기관에서 제공되는 감각 정보가 말 산출 을 위한 운동 및 협응 능력에서 통제되어야 하는 것을 말한다. 그리 고 이 모델에서는 말 산출의 전 과정을 중요한 요소로 보기 때문에, 턱, 입술, 혀, 성대 및 호흡기관으로부터의 운동범위 조절, 협응 등 이 제대로 통제되지 않으면 말 산출이 정상적으로 되지 못한다고 설명한다(Kent \& Lass, 1976; Sim, 2001). 이 모델에서는 최대발성시 간(maximum phonation time), 최대반복속도(maximum repetition rate), 혀와 입술 운동통제 능력, 시지각적 운동추적 능력(vi- 
suomotor tracking), 모음 공간 크기, 타이밍 통제능력을 중요 평가 지표로 제시하고 있으며, 말 산출의 복잡한 과정 중에서 하나에서 라도 문제가 생기면 말소리 산출에 장애가 나타날 수 있다고 간주 하는 것이다.

운동통제 능력은 호흡, 발성, 조음기관 운동의 적절성 측면을 평 가하며(Sim, 2001), 기능적 조음음운장애 아동의 말 운동통제 능 력을 측정하기 위해서 조음기관의 운동능력 적절성을 평가하는 것 이 일반적이다. 선행연구(Cohen \& Waters, 1999; Ha, 2000; Hong \& Sim, 2011; Towne, 1994)에서는 기능적 조음음운장애 아동의 말 소리 오류의 원인이 불분명하였기 때문에 말소리 오류를 운동능력 저하와 관련하여 설명하고자 하였으며, 이와 관련하여 조음 속도, 조음기관의 운동통제에 대한 연구가 진행되어 왔다. 기능적 조음 음운장애 아동의 교대운동속도는 일반 아동에 비해서 유의하게 느리며, 교대운동속도에서의 변이성도 일반 아동에 비해서 더 큰 것으로 보고되었다(Ha, 2000; Towne, 1994). Cohen과 Waters (1999) 가 취학 전 조음음운장애 아동과 일반 아동의 조음 속도를 비교해 본 결과, 기능적 조음음운장애 아동의 조음 속도가 일반 아동에 비 해서 유의하게 느렸다. Hong과 $\operatorname{Sim}$ (2011)이 기능적 조음음운장애 아동의 문장 길이에 따른 말속도를 살펴본 결과에서도 기능적 조 음음운장애 아동의 말속도의 가변성이 일반 아동에 비해서 더 크 고 문장의 길이가 길어질수록 조음 오류도 크게 증가하는 것으로 나타났다. 이러한 결과들은 기능적 조음음운장애 아동의 말소리 산출 문제는 말 운동통제 능력의 취약성과 말 운동 프로그래밍이 관련되어 있음을 시사한다.

성대진동시작시간(voice onset time, VOT)은 파열음의 파열 이 후부터 후행 모음의 발성까지 걸리는 시간을 말하며, VOT 측정을 통해서 파열음 산출시의 후두와 상후두 기관(입술, 혀, 턱)의 협응 능력과 특성에 대한 정보를 알 수 있다(Grigos, Saxman, \& Gordon, 2005; Kent \& Read, 2002; Yoo \& Kim, 2015). VOT는 시간 음향학 적인 분석에서 타이밍 조절에 관한 객관적인 지표로 사용될 수 있 으며(Auzou et al., 2000), 말소리 오류의 원인을 파악하는 데 정보를 제공할 수 있다(Kim, Kang, \& Kim, 2002; Oh, Zhi, \& Kim, 2000; Pouplier, Marin, \& Waltl, 2014). 말장애인의 VOT 측정은 음향학 적 특성, 타이밍 통제능력(timing control ability), 생리학적 체계를 간접적으로 이해하는 데 도움을 줄수 있다(Ann, 2002; Hong, Kim, Yoon, Park, \& Hong, 2012; Jeong, Kim, Sim, \& Park, 2011).

뇌성마비, 실어증, 파킨슨병을 지닌 말장애인의 VOT에 관한 선행 연구(Auzou et al., 2000; Kim et al., 2002; Lee, 2013; Morris, 1989; Park et al., 2006)에서는 말장애인과 일반인의 VOT에 유의한 차이 가 있다고 보고하고 있다. Ann (2002)이 10세에서 16세 사이의 경
직형 뇌성마비 아동 $(\mathrm{N}=14)$ 과 일반 아동 $(\mathrm{N}=14)$ 을 대상으로 /삐/, /匹/, / T/와// /, / / /, / T/를 결합한 VCV음절에서 VOT를 측정한 결과, VOT가 조음위치에 따라 집단 간 뚜렷한 차이를 보였으며, /아빠/,/우뚜/, /이끼/,/우꾸/를 제외하고 일반아동에 비해 유의미하 게 길었다. Park 등(2006)은 한국인 파킨슨병 화자 $(\mathrm{N}=15)$, 일본인 파킨슨병 화자 $(\mathrm{N}=20)$, 한국인 정상 화자 $(\mathrm{N}=7)$, 일본인 정상 화 자 $(\mathrm{N}=7)$ 를 대상으로 한국어의 평음, 일본어의 유성음을 제외한 파열음을 선행하는 모음/게/와 후행하는 모음//로 만든 $\mathrm{VCV}$ 음 절을 문장에 넣어 산출하도록 한 후 VOT를 측정한 결과, 한국인과 일본인 모두 파킨슨병을 지닌 화자의 VOT가 정상 화자에 비해서 유의하게 길었다. $\operatorname{Kim}$ 등(2002)이 비유창성 실어증 환자를 대상으 로 의미가 있는 단음절(/벌/, /닭/, /곰/)에서 파열음의 음향분석을 실시한 결과, 비유창성 실어증 환자의 양순음과 연구개음에서의 VOT가 정상 화자에 비해서 유의하게 길었으며, 비유창성 실어증 환자의 음성 왜곡 문제로 인해서 조음위치에 따른 VOT가 폐쇄구 간과 VOT 구간이 중첩되는 특징을 보이기도 하였다. 이러한 선행 연구 결과는 뇌성마비, 실어증, 파킨슨병을 지닌 화자의 조음기관 의 시간 협응 능력의 부족과 음성 왜곡 현상이 VOT에 영향을 미칠 수 있음을 시사한다(Ann, 2002; Auzou et al., 2000; Kim et al., 2002; Park et al., 2006).

청각장애로 인한 말장애 집단의 VOT 선행연구(Lee, 2009; Oh et al., 2000)에서 청각장애 아동과 일반 아동 간의 VOT에 유의한 차 이를 보이지 않는다고 보고하고 있다. Oh 등(2000)은 6-10세의 고 도 이상의 난청을 지닌 청각장애 아동 $(\mathrm{N}=20)$ 과 정상청력 아동 $(\mathrm{N}=20)$ 을 대상으로 양순, 치조, 연구개 파열음과 선.후행하는 모음 / / 기로 구성한 VCV음절에 대한 VOT를 측정한 결과, 청각장애 아 동과 정상청력 아동 간의 조음위치에 따른 VOT에는 유의한 차이 가 없었다. Lee (2009)는 6-9세의 인공와우 아동 $(\mathrm{N}=15)$ 과 정상청 력 아동 $(\mathrm{N}=15)$ 을 대상으로 문장 속에서 $\mathrm{VCV}$ 음절을 이용한 양순 음, 치조음, 연구개음의 VOT를 측정한 결과에서도 두 집단 간의 VOT에 유의한 차이가 없었다. 이러한 선행연구 결과는 조음 구조 문제가 동반되지 않는 말장애인의 경우에는 파열음 산출에 필요한 후두와 후두상부 기관의 협응에는 문제가 없으며, 말 산출의 다른 단계에서의 결함으로 말 문제가 발생된다는 것을 시사한다. 청각장 애 아동의 경우, 보청기나 인공와우와 같은 청각보조기기의 사용으 로 청각적 피드백이 상당한 수준까지 발달하고 말 산출에서도 일반 아동과 유사한 자음정확도를 성취하기 때문에, 일반 아동과 청각 장애 아동 간의 VOT에 유의한차이가 나타나지 않았을 수도 있다.

구조적 문제가 없는 말소리장애 아동의 VOT 연구를 살펴보았 을 때, 말소리장애 아동과 일반 아동의 VOT 비교 분석 결과가 상 
이하게 보고되고 있다. $\mathrm{Yu}$ 등(2014)이 구어운동산출평가(Verbal Motor Production Assessment for Children)에서 중등도(moderate to severe)로 진단된 취학 전의 말소리장애 아동 $(\mathrm{N}=6)$ 과 일반 아동 $(\mathrm{N}=6)$ 에게 $/ \mathrm{pa} /$ 를 산출하도록 하여 VOT를 측정한 결과, 두 집단 간에 양순파열음의 VOT에는 유의한 차이가 없었다. Lundeborg, Nordin, Zeipel-Stjerna 그리고 McAllister (2015)가 취학전 $(\mathrm{N}=18)$, 저학년 $(\mathrm{N}=13)$, 고학년 $(\mathrm{N}=7)$ 의 음운장애(phonological impairment) 세 집단을 대상으로 $/ \mathrm{p}, \mathrm{b}, \mathrm{t}, \mathrm{d}, \mathrm{k}, \mathrm{g}$ 로 구성된 6개의 최 소쌍의 VOT를 연령 집단 내에서 비교를 하였으며, Lundeborg, Larsson, Wiman, 그리고 Mcallister (2012)의 일반 아동의 VOT 규준과 비교해보았다. 그 결과, 일반 아동의 VOT에서는 연령 증가에 따라 서 VOT가 짧아지는 경향을 보이는 데 반해서, 취학전, 저학년, 고 학년의 음운장애 아동의 VOT는 연령이 증가함에도 VOT에서 유 의한 차이가 나타나지 않았다. 그리고 음운장애 아동의 세 집단에 서 조음위치에 따른 VOT 변화도 유의하게 나타나지 않았다. Lundeborg 등(2015)은 음운장애 아동의 VOT가 일반 아동과 발 달 경향이 다른 점에 대해서 말소리장애 아동의 말소리 조절 능력 의 미숙성과 비정상성에 대해서 언급을 하였다.

VOT는 연령에 따라서 차이가 나타나기 때문에 말 산출 능력을 평가하는 지표로 활용될 수 있다(Lee \& Lee, 2015; Vickie, De Nil, \& Pang, 2015; Whiteside \& Marshall, 1998, 2001; Yoo \& Kim, 2015). Lee와 Lee (2015)가 취학전 아동 $(\mathrm{N}=25)$, 학령기 아동 $(\mathrm{N}=25)$, 성 인 $(\mathrm{N}=25)$ 의 양순, 치조, 연구개 파열음에 모음/가를 결합한 VCV 음절에서 VOT를 비교해 본 결과, 취학전 아동의 VOT가 학령기 아 동과 성인에 비해서 유의하게 길었으며, 학령기 아동과 성인 간의 VOT는 유의한 차이가 없었다. Whiteside와 Marshall (1998)이 영 어를 사용하는 7세 아동 $(\mathrm{N}=10), 9$ 세 아동 $(\mathrm{N}=10), 11$ 세 아동 $(\mathrm{N}=10)$ 의 무성 양순음 $/ \mathrm{p} /$, 유성 양순음 $/ \mathrm{b} /$, 무성 치조음 $/ \mathrm{t} /$, 유성 치조음 $/ \mathrm{d} /$ 를 모음 $/ \mathrm{i} /$ 와 결합하여 VOT를 측정한 결과, 유성 양순음과 유 성 치조음에서 아동의 연령이 어릴수록 VOT가 길어지는 것으로 나타났다. 또한 Whiteside와 Marshall (2001)은 무성음 /pi/, /ti/와 유성음 /bi/, /di/를 7세, 9세, 11세 아동을 대상으로 비교한 VOT 연 구에서 연령이 증가할수록 VOT가 짧아지다가 11세가 되면 성인과 비슷한 VOT에 도달하는 것으로 나타났다. Vickie 등(2015)은 취학 전 아동, 학령기 아동, 청소년, 성인을 대상으로 무성음 $/ \mathrm{p} /, / \mathrm{k} /$ 를 단 음절 $/ \mathrm{pa}$ /와 다음절 /pataka/ 조건에서 VOT를 측정하였다. 그 결 과, 단음절과 다음절 조건에서 연령이 증가할수록 VOT가 짧았으 며, 11 세 이상부터의 연령 집단의 VOT는 성인 집단과 유의미한 차 이를 보이지 않았다. 이러한 선행연구 결과는 VOT의 변화가 연령 과 밀접한 관련이 있으며, 연령이 증가함에 따라서 VOT도 안정화
되는 것을 시사한다. 즉, $\mathrm{VOT}$ 측정을 통해서 아동의 조음기관의 폐 쇄와 개방의 연속적인 운동을 제어할 수 있는 능력을 살펴볼 수 있 는 것이다.

파열음의 조음위치와 발성유형이 VOT에 영향을 미치며, 두 가 지 요인이 동시에 VOT에 영향을 미친다고 알려져 있다(Broersma, 2010; Lee \& Lee, 2015; Pae, Shin, \& Ko, 1999). 파열음의 조음위치 에서 살펴보면, 양순음, 치조음, 연구개음 중에서 후방에서 산출되 는 자음일수록 VOT가 유의하게 길었으며, 이는 VOT 측정에 사용 된 음절구조('VC', 'VCV')에 상관없이 동일하게 나타났다(Hong, Kang, \& Kim, 2015; Pae et al., 1999). 언어에 따라서 파열음 산출시 에 VOT의 정지 구간에는 차이가 발생되지만, 조음위치에 따라서 파열음을 구분하면 화자의 언어와 무관하게 양순음의 VOT가 치 조음과 연구개음의 VOT보다 짧게 나타났으며(Cho \& Ladefoged, 1999), 화자의 연령과는 무관하게 정상적인 말 발달의 아동과 성인 모두에게서 전방 자음의 VOT가 후방 자음의 VOT보다 유의하게 짧았다(Lee \& Iverson, 2008).

파열음은 발성유형에 따라서 평음, 경음, 격음으로 분류하며, 파 열음의 기식성에 비례하여 VOT가 길어진다(Broersma, 2010; Jeong et al., 2011). Pae 등(1999)는 20대 성인 화자를 대상으로 다양한 음 절에서 파열음의 VOT를 측정한 결과, 모든 음절에서 격음이 가장 길게 나타났음을 보고하였다. Cho와 Ladefoged (1999)가 측정한 18 개 언어의 파열음 중 무기음과 유기음의 VOT를 비교한 결과에 서도 기식성을 지닌 유기음의 VOT가 무기음의 VOT보다 길게 측 정되었다. Jeong 등(2011)은 운동 기능성 수준(고, 저)에 따라서 뇌 성마비 아동을 구분하고 선·후행하는 모음을/ / / 로 고정한 후 VCV 음절에서의 VOT를 측정하여, 정상 말발달 아동과의 VOT를 비교 해보았다. 그 결과, 운동 기능성의 고, 저에 따른 뇌성마비 아동과 정상 말발달 아동 모두에서 격음의 VOT가 평음과 경음에 비해서 유의하게 길었다. 이러한 선행연구 결과는 말장애 유무에 상관없이 발성유형이 VOT에 영향을 미치며, 특히 기식성의 여부가 VOT에 유의한 영향을 미친다는 것을 의미한다.

기능적 조음음운장애 아동의 말 운동통제 능력은 직접적으로 평가하기 힘들며, 이로 인해서 말소리 오류의 원인을 파악하는 것 은 더 어려운 측면이 있다. 기능적 조음음운장애 아동의 말소리 오 류가 연구자나 임상가에게 청지각적으로 동일하게 판단되더라도 원인이나 관련 요인은 다를 수 있으며, 복합적인 원인으로 인해서 말소리 오류가 나타날 수도 있다. 그러므로 본 연구에서는 말소리 오류의 복합적인 요인 중에서 후두와 상후두 기관의 협응 능력과 관련하여 기능적 조음음운장애 아동의 말소리 오류에 대한 특징 과 일반 아동과의 차이점을 확인하고자 하였다. 본 연구에서는 한 
국어 파열음을 모두 분석하여 한국어 파열음에 대한 전반적인 특 징을 확인하고, 이와 관련하여 타이밍 통제능력이 파열음 산출에 부정적인 영향을 미치는지 알아보고자 하였다. 이에 본 연구에서 는 기능적 조음음운장애 아동이 정조음하는 파열음 산출과 관련 하여 말 타이밍 조절 및 생리적 기제가 일반 아동과 차이가 있는지 를 논의해 보고자 하였다. 따라서 본 연구에서는 집단(기능적 조음 음운장애 아동, 일반 아동), 파열음의 조음위치(양순음, 치조음, 연 구개음), 발성유형(평음, 경음, 격음)에 따른 VOT 차이를 살펴보고 자하였다.

\section{연구방법}

\section{연구 대상}

본 연구의 대상은 만 3 세 9 개월부터 8 세 11 개월의 대전 및 충남 지역에 거주하는 기능적 조음음운장애 15 명과 말.언어 발달에 문 제가 없는 일반 아동 15 명으로, 아래의 선정기준을 충족하는 대상 자만을 실험에 참여시켰다.

기능적 조음음운장애 아동은 (1) 수용 및 표현어휘력 검사(Receptive \& Expressive Vocabulary Test, REVT; Kim et al., 2009) 결 과가 자신의 생활연령 범위 혹은 그 이상이며, (2) 아동용발음평가 (Assessment of Phonology for Children, APAC; Kim, Pae, \& Park, 2007)에서 자음정확도가 -2 표준편차 이하이면서, (3) 발달장애, 정 서장애, 지적장애, 지체장애 등을 동반하지 않은 아동만을 대상으 로 선정하였다. 일반 아동은 (1) 수용 및 표현어휘력 검사(Kim et al., 2009) 결과가 자신의 생활연령 범위 혹은 그 이상이며, (2) 아동 용발음평가(Kim et al., 2007)에서 자음정확도가 -1 표준편차 이상 이며, (3) 부모 및 유치원 교사로부터 정상적인 말-언어 발달을 보이 고 있다고 보고된 아동만을 대상으로 선정하였다. 연령으로 인한 VOT 변화를 통제하기 위해서(Whiteside \& Marshall, 2001), 일반 아동은 조음음운장애 아동의 생활월령을 기준( \pm 3 개월 $)$ 으로 일 치시켰다.

대상 아동의 생활연령과 자음정확도에 대한 기술통계 결과는 Table 1 과 같다. 기능적 조음음운장애 아동과 일반 아동의 생활연

Table 1. Participants' information

\begin{tabular}{lcc}
\hline & FAD (N=15) & TSD (N=15) \\
\hline Gender (male:female) & $6: 9$ & $9: 6$ \\
Chronological age $(\mathrm{mo})$ & $65.27(16.14)$ & $68.13(15.42)$ \\
PCC $(\%)$ & $76.75(17.63)$ & $98.09(3.62)$ \\
\hline
\end{tabular}

Values are presented as mean (SD).

FAD = children with functional articulation disorders; TSD = children with typical speech development; $\mathrm{PCC}=$ percentage of consonants correct.
령과 자음정확도에 대한 동질성 검정을 위해서 독립표본 $t$-검정을 실시하였다. 그 결과, 생활연령에서는 유의한 차이를 보이지 않았으 며 $\left(t_{(28)}=-.497, p>.05\right)$, 자음정확도에서는 일반 아동의 자음정확도 가 기능적 조음음운장애 아동보다 유의하게 높았다 $\left(t_{(28)}=-4.590\right.$, $p<.001)$. 성별에 따른 VOT에 차이가 있는지를 살펴보기 위해서, 집단에 따른 9 개 음절의 VOT에 관하여 독립표본 $t$-검정을 실시한 결과, 전체 30 명의 아동에서 9 개의 음절 모두에서 성별에 따른 VOT 차이가 유의하지 않았다(all $p>.05)$. 또한 각 집단 내에서 성별에 따 른 VOT에 차이가 있는지 살펴보기 위해서 Mann-Whitney 검정을 실시한 결과, 9 개 음절 모두에서 조음음운장애 아동(all $p>.05$ )과 일반 아동(all $p>.05$ ) 내에서 각 성별에 따른 VOT에 유의한 차이가 없었다.

\section{검사 자료}

검사 자료는 조음위치와 발성유형의 종류를 다르게 하여 총 9 개 (3개의 조음위치 $\times 3$ 개의 발성유형)의 VCV (모음+자음+모음)음 절로 구성하였다. 파열음으로 VOT를 살펴보는 것이 파열 이후 성 대가 진동하기 시작하는 구간을 가장 잘 확인할 수 있기 때문에 (Auzou et al., 2000), 검사 자료를 파열음 계열의 목표 자음에 선·후 행모음인/F/를 결합한 음절 '아바', '아빠', '아파', '아다', '아따', '아 타,' '아가', '아까', '아카'로 구성하였다(Table 2).

\section{자료 녹음}

자료 수집은 아동의 집, 유치원 또는 언어치료실의 조용한 공간 에서 단일 지향성 마이크(SURE MX183-X)와 디지털레코더(EDIROL R-05HR)를 이용하여 아동의 발화를 녹음하였다. 아동의 입 과 마이크 사이의 거리는 $15 \mathrm{~cm}$ 를 유지하였으며, 연구자가 목표 음 절을 말하는 모습을 아동에게 보여준 후 아동이 자연스럽고 편안 한 상태에서 목표 음절을 따라말하도록 하였다. 이때, 아동의 말 속 도를 조절하기 위해서 손가락 카운팅 방법으로 시각적 단서를 제시 하였으며, 5 회 모두 모델링을 제시하여 따라말하도록 하였다. 녹음 시 표본추출률은 $44,100 \mathrm{~Hz}$, 양자화는 $16 \mathrm{bit}$ 였고, 추후 분석 시에 는 $44,100 \mathrm{~Hz}$ 로 다운샘플링하였다.

Table 2. List of syllable by place of articulation and phonation type

\begin{tabular}{llcc}
\hline \multirow{2}{*}{ Place of articulation } & \multicolumn{3}{c}{ Phonation type } \\
\cline { 2 - 4 } & Lenis & Fortis & Aspirate \\
\hline Bilabials & /apa/ & /ap*a/ & $/ a p^{\mathrm{h}} \mathrm{a} /$ \\
Alveolars & /ata/ & $/ \mathrm{at}^{*} \mathrm{a} /$ & $/ \mathrm{ath}^{\mathrm{h}} \mathrm{a} /$ \\
Velars & /aka/ & $/ \mathrm{ak}^{*} \mathrm{a} /$ & $/ \mathrm{k}^{\mathrm{h}} \mathrm{a} /$ \\
\hline
\end{tabular}




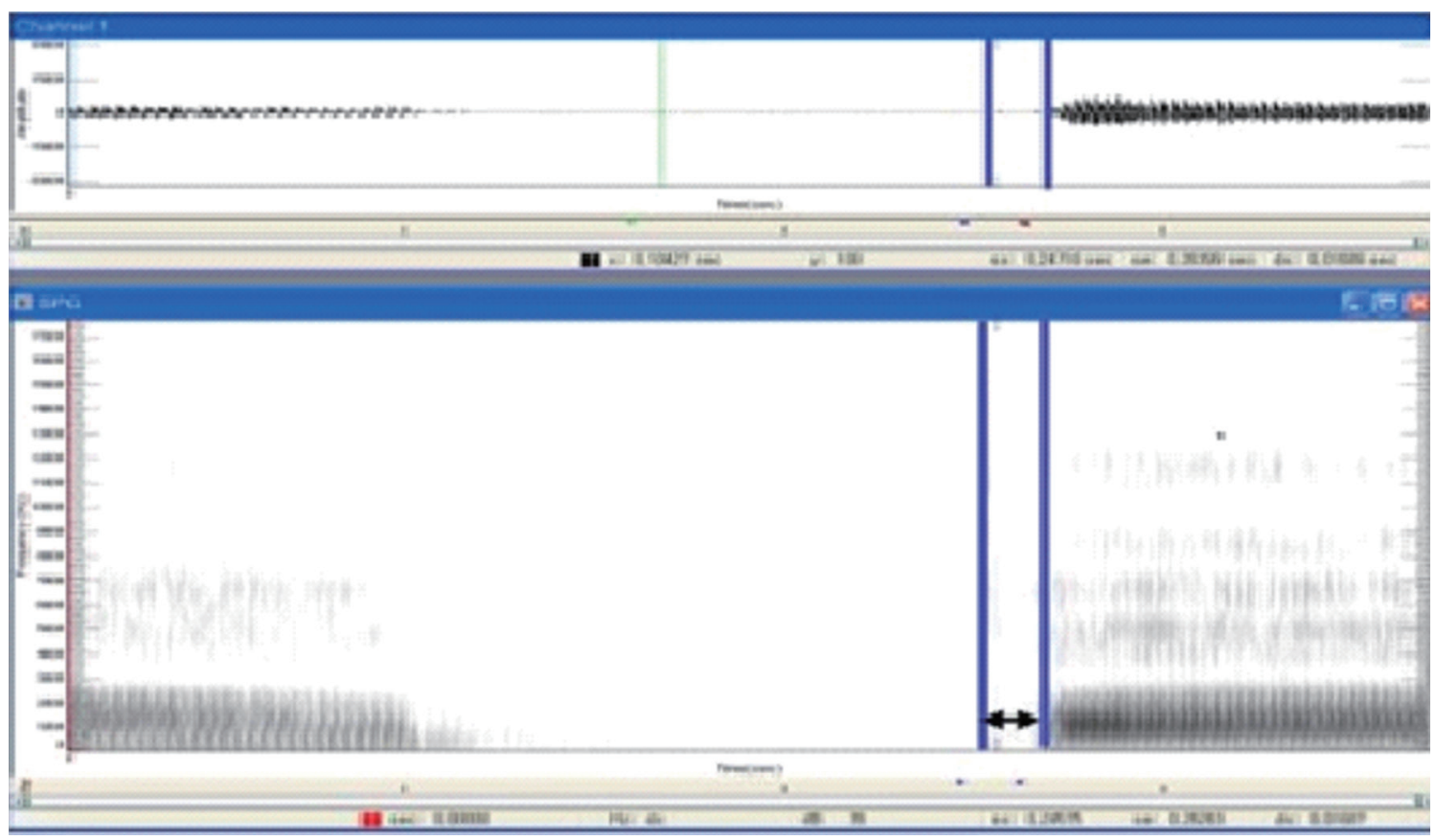

Figure 1. Example of voice onset time measurement of the /ap*a/. The symbol $(\leftrightarrow)$ means a duration of the period of time between the release of a plosive /ap*a/ and the beginning of vocal fold vibration.

\section{자료 분석}

CSL (Computerized Speech Lab, model 4500; Kay PENTAX Elemetrics, Lincoln Park, NJ, USA)을 사용하여, 아동이 산출한 9개 의 음절의 VOT를 측정하였다. VOT는 파열이 일어난 지점부터 후 행모음인 / / / 파형이 시작되기 전까지의 구간이며(Whiteside와 Marshall, 1998), 모음 사이에서 유성음화 되는 평음의 경우, 한국 어 파열음 특성을 연구한 Seo (2002)의 측정 방법을 따라 선행하는 모음의 포먼트가 끝나는 지점을 측정하였으며, 이때 정확한 VOT 측정을 위해서 스펙트로그램, 포먼트 정보, 녹음된 음성을 비교하 였다(Figure 1). 아동에게 음절별로 5회씩 산출하게 한 뒤 가운데 3 개 음절의 VOT를 측정하여 평균을 산출하였다.

\section{신뢰도 및 통계적 처리}

전체 음성 샘플의 $20 \%$ 를 임의로 추출하여 제 1 검사자의 VOT 측 정치와 제 2 검사자의 VOT측정치를 피어슨 상관계수로 비교하여 분석한 결과 검사자 간 신뢰도는 .748 $(p<.01)$ 이며, 제 1 연구자의 1 차와 2차 VOT 측정치를 비교한 검사자 내 신뢰도는 .817 $(p<.01)$ 이었다. 조음위치와 발성유형에 따른 음절의 VOT를 반복 측정한 평균값을 통계 처리에 사용하였으며, 통계 분석을 위해서 PASW ver. 18.0 프로그램을 사용하였다. 파열음의 조음위치(양순음, 치조 음, 연구개음)와 발성유형(평음, 경음, 격음)에 따른 집단(기능적 조
음음운장애 아동, 일반 아동) 간의 VOT에 차이가 있는지 살펴보 기 위해서 삼원혼합분산분석(three-way mixed ANOVA)을 실시 하였다. 주효과에 대한 사후검정 실시에서 다중비교로 인한 1종 오 류 증가를 조절하기 위해서 Bonferroni alpha correction을 실시한 값으로 유의수준을 해석하였다.

\section{연구결과}

파열음의 조음위치와 발성유형에 따른 집단 간 VOT의 결과는 Table 3과 같다.

구형성 가정을 검정한 결과, 발성유형(Mauchly's $\mathrm{W}=.168, \chi^{2}=$ $48.099, p<.001)$, 조음위치와 발성유형(Mauchly's W=.178, $\chi^{2}=45.526$, $p<.001)$ 에서 동질성 가정이 위배되는 것으로 나타나서, Greenhouse-Geisser의 F값을 토대로 결과를 해석하였다.

삼원혼합분산분석을 실시한 결과, 집단에 대한 주효과는 유의하 지 않아서 $\left(F_{(1,28)}=.682, p>.05\right)$, 기능적 조음음운장애 아동과 일반 아동 간의 VOT에는 유의한 차이가 없는 것으로 나타났다. 조음위 치에 대한 주효과는 유의하였다 $\left(F_{(1.870,70.766)}=57.843, p<.001\right)$. 이에 Bonferroni 사후검정을 실시한 결과, 양순음과 연구개음 $(p<.001)$, 치조음과 연구개음 $(p<.001)$ 간의 VOT에서 유의한 차이를 보였다. 즉, 두 집단 모두에서 연구개음의 VOT가 양순음과 치조음의 VOT 
Table 3. Descriptive data of voice onset time for place of articulation and phonation type of plosive by group

\begin{tabular}{lccr}
\hline Place of articulation & Phonation type & FAD (N=15) & TSD (N=15) \\
\hline Bilabials & /apa/ & $11.12(2.92)$ & $9.30(4.17)$ \\
& /ap*a/ & $11.05(3.24)$ & $9.70(1.81)$ \\
Alveolars & /apha/ & $37.95(9.85)$ & $34.33(9.66)$ \\
& /ata/ & $13.44(2.47)$ & $13.67(2.86)$ \\
& /at*a/ & $11.53(2.28)$ & $10.14(2.02)$ \\
Velars & /at"a/ & $39.77(11.5)$ & $35.98(9.07)$ \\
& /aka/ & $24.06(6.08)$ & $21.57(4.87)$ \\
& /ak*a/ & $23.33(3.57)$ & $26.93(5.40)$ \\
& /akha/ & $60.89(15.6)$ & $67.04(9.49)$ \\
\hline
\end{tabular}

Values are presented as mean (SD).

$\mathrm{FAD}=$ children with functional articulation disorders; $\mathrm{TSD}=$ children with typical speech development.

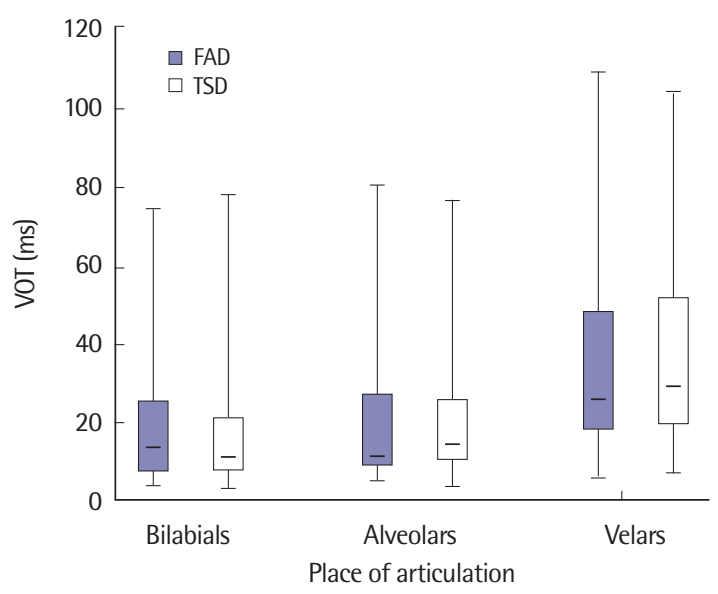

Figure 2. Voice onset time (VOT) for place of articulation for children with functional articulation disorders (FAD) and children with typical speech development (TSD).

보다 유의하게 길었다(Figure 2). 발성유형에 대한 주효과도 유의하 였으며 $\left(F_{(1.092,70.766)}=61.941, p<.001\right)$, Bonferroni 사후검정을 실시 한 결과, 평음과 격음 $(p<.001)$, 경음과 격음 $(p<.001)$ 간의 VOT에 서 유의한 차이를 보였다. 즉, 격음에서의 VOT가 평음과 경음에 비 해서 유의하게 길게 나타났다(Figure 3).

조음위치와 발성유형이 VOT에 미치는 이차 상호작용 효과가 유 의하게 나타났다 $\left(F_{(2.527,70.766)}=4.197, p<.05\right)$. 이에 MMATRIX 명령 어를 사용하여 상호작용 대비검정을 실시한 결과, 격음에서의 치조 음과 연구개음의 VOT 차이가 평음에서 치조음과 연구개음의 VOT 차이보다 유의하게 큰 것으로 나타났다 $(p<.01)$. 즉, 이차 상호작용 효과는 치조음에 비해서 연구개음의 VOT가 평음에 비해서 격음 에서 유의하게 길어지면서 나타난 것으로 보여진다(Figure 4).

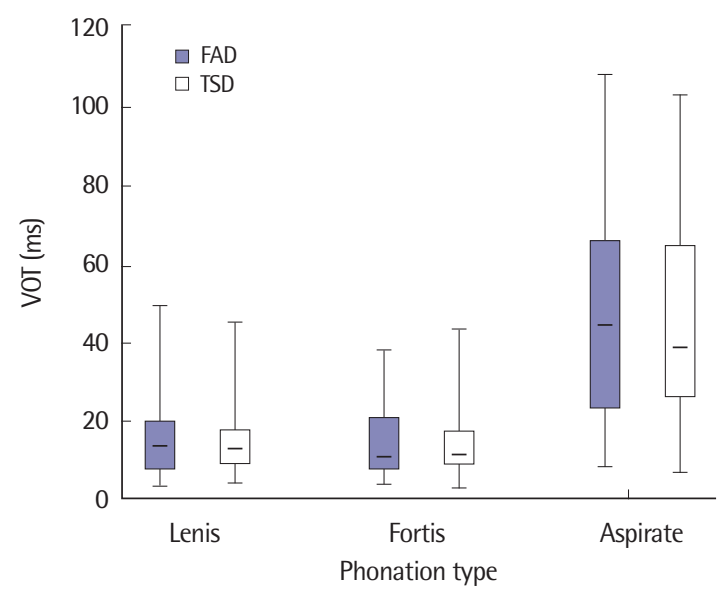

Figure 3. Voice onset time (VOT) for phonation type for children with functional articulation disorders (FAD) and children with typical speech development (TSD).

\section{논의 및 결론}

본 연구에서는 파열음의 조음위치와 발성유형에 따른 기능적 조 음음운장애 아동과 일반 아동 간의 VOT에 차이가 있는지 살펴보 았다. 연구 결과, 두 집단 간의 VOT에는 유의한 차이가 없었으나, 조음위치와 발성유형에 따른 VOT에는 유의한 차이를 보였다. 조 음위치에서는 연구개음의 VOT가 양순음과 치조음에 비해서 유의 하게 길었으며, 발성유형에서는 격음의 VOT는 평음과 경음에 비해 서 유의하게 길었다.

본 연구에서 기능적 조음음운장애 아동과 일반 아동의 VOT에 유의한차이를 보이지 않았다. Lundeborg 등(2015)이 취학 전( $(\mathrm{N}=18)$, 저학년 $(\mathrm{N}=13)$, 고학년 $(\mathrm{N}=7)$ 의 음운장애 아동을 대상으로 $/ \mathrm{p}, \mathrm{b}$, $\mathrm{t}, \mathrm{d}, \mathrm{k}, \mathrm{g}$ 로 구성된 6개의 최소쌍의 VOT를 일반아동과 비교해 본 결과, VOT에서 유의한 차이를 보였다. 이러한 결과 차이는 대상자 의 연령에 기인한 것으로 보여진다. 본 연구에서는 취학 전과 초등 학교 저학년의 어린 연령의 아동만을 대상으로 하였으나, Lundeborg 등(2015)의 연구에서는 초등학교 고학년의 아동도 포함되어 있다. 즉, 초등학교 고학년부터는 성인의 VOT 형태로 발달한다는 선행연구(Whiteside \& Marshall, 2001; Vickie et al., 2015)를 고려 할 때, 초등학교 고학년을 포함시킴으로써 음운장애 아동과 일반 아동 간의 VOT 차이가 유의하게 나타났을 것으로 생각된다. Park과 Byeon (2015)이 발달성말실행증 아동 $(\mathrm{N}=6)$ 과 일반 아동 $(\mathrm{N}=10)$ 을 대상으로 경음의 조음위치에 따라 $\mathrm{CV}$ 음절에서 $\mathrm{VOT}$ 를 측정한 결과 두 집단 간에 조음위치에 따른 VOT는 유의한 차이가 없었다. 이러한 경향은 말장애 아동뿐만 아니라 신경 문제로 말장애가 야 

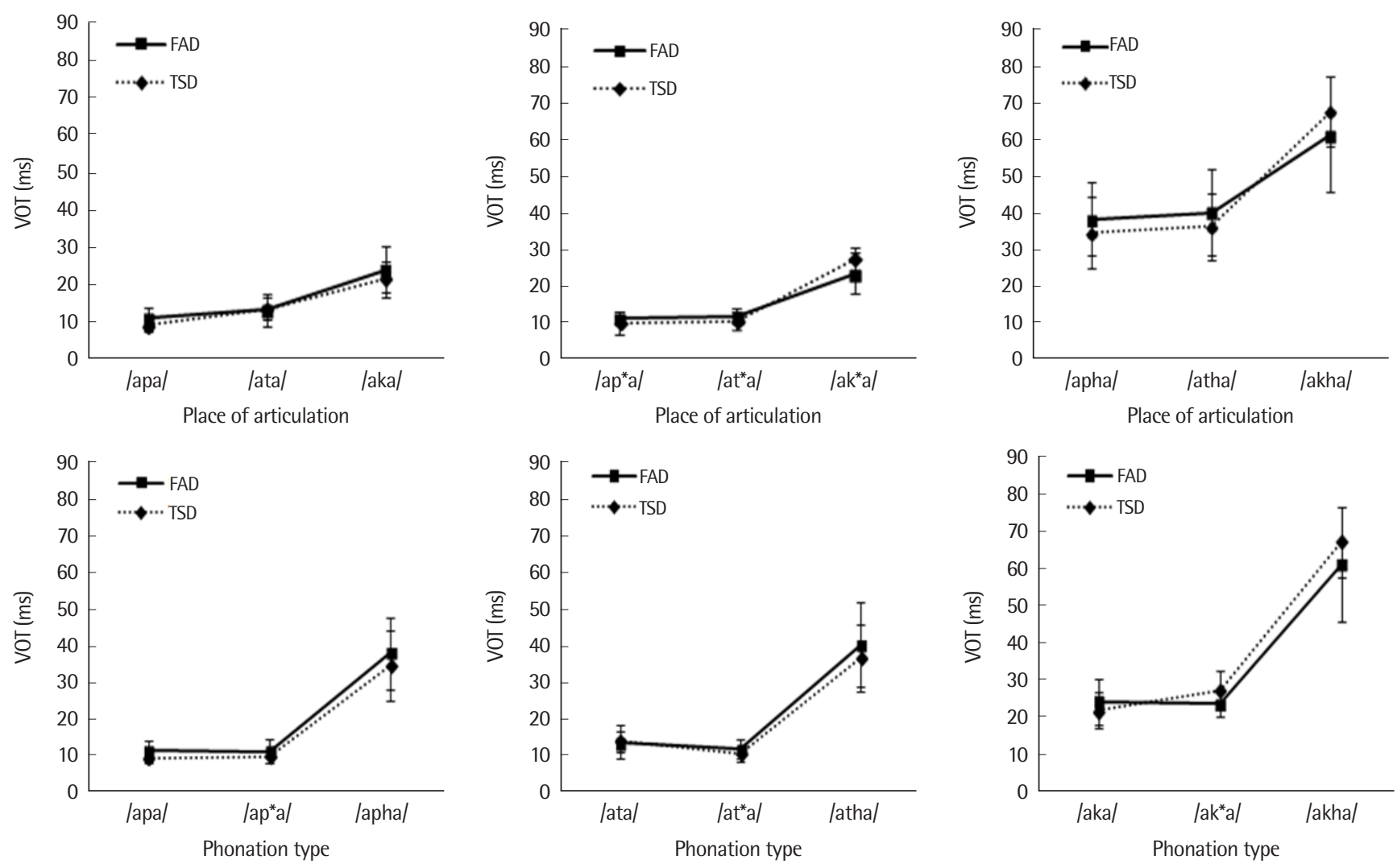

Figure 4. Voice onset time (VOT) for place of articulation and phonation type for children with functional articulation disorders (FAD) and children with typical speech development (TSD).

기된 성인에게도 일관되게 보고되고 있다. Harel 등(2004)이 파키 슨병으로 조음 문제를 지닌 성인 $(\mathrm{N}=2)$ 과 연령을 일치시킨 일반 성 인 $(\mathrm{N}=2)$ 의 자발화에서 발췌한 'to', 'two', 'too'에서의 VOT를 측정 한 결과에서도 두 집단 간의 VOT에는 유의한 차이가 없었다. 하지 만 Lee (2013)가 경직형 마비말장애인을 대상으로 VCV음절에서 파열음 경음의 $\mathrm{VOT}$ 를 측정한 결과에서는 조음중증도가 경중등 도(mild-to-moderate)인 집단의 VOT가 경도인 집단에 비해서 유 의하게 길게 나타났으며, 경직형 뇌성마비 아동의 VOT도 일반 아 동에 비해 더 길었다고 보고하였다(Ann, 2002). 이러한 결과들은 말장애의 기저에 따라서 VOT가 일반인과 다른 형태를 보인다는 것을 시사한다. 즉, 뇌성마비로 인한 말장애를 지닐 경우에는 전반 적인 운동 능력 저하가 후두와 상후두 협응에도 부정적인 영향을 주어서 말 운동 타이밍 통제능력이 일반인에 비해서 저하되는 것이 다. 반면에, 기능적인 말장애를 지닐 경우에는 말 운동 타이밍 통제 능력은 결함없이 보존되며, 이는 기능적 조음음운장애 아동의 말 문제의 기저가 타이밍 통제능력보다는 다른 말 운동능력의 저하, 결함에 기인한다는 것을 시사한다.

본 연구에서는 파열음의 조음위치에 따른 VOT에 유의한 차이
가 있었으며, 두 집단 모두에서 연구개음의 VOT가 양순음과 치조 음에 비해서 유의하게 길었다. 후방 자음의 VOT가 전방 자음보다 길게 나타나는 특성은 연령에 상관없이 일관적으로 나타나는 특성 이다(Bóna, 2014; Lee \& Iverson, 2008; Lee \& Lee, 2015). Lee와 Lee (2015)가 다양한 연령대의 화자(취학전, 학령기, 성인)를 대상으로 양순음, 치조음, 연구개음의 VOT를 측정한 결과, 세 집단 모두 연 구개음의 VOT가 양순음과 치조음의 VOT보다 유의하게 길었다. Lee와 Iverson (2008)이 정상적인 말 발달을 하는 아동 $(\mathrm{N}=30)$ 을 대상으로 9 개의 단어(발, 빨강, 팔, 다리, 딸기, 타조, 가방, 까망, 칼) 에서 VOT 측정하여 한국어 파열음 발달을 살펴본 결과에서도 연 구개음에서의 VOT가 양순음과 치조음에서보다 유의하게 길게 나 타났다. Bóna (2014)는 다양한 음절('CV', 'VCV', 'CCV')로 구성되 어 있는 13 개 문장에서 청년 $(\mathrm{N}=25)$ 과 노인 $(\mathrm{N}=25)$ 의 무성파열음 $(/ \mathrm{p}, \mathrm{t}, \mathrm{k} /) \mathrm{VOT}$ 를 측정한 결과, 연구개음의 VOT가 양순음의 VOT 에 비해서 유의하게 길었다.

Kang 등(2009)은 파킨슨병 환자와 정상노인의 VOT를 측정한 결과, 두 집단 모두 양순음과 치조음에 비해 연구개음의 VOT가 길 게 나타났다. Fischer와 Goberman (2010)이 파킨슨병 환자 $(\mathrm{N}=9)$ 
를 대상으로 유성음 $(/ \mathrm{b} /, / \mathrm{d} /, / \mathrm{g} /)$ 과 무성음 $(/ \mathrm{p} /, / \mathrm{t} /, / \mathrm{k} /)$ 을 모음 $(/ \mathrm{a} /$, $/ \mathrm{i} /, / \mathrm{u} /, / \Re /)$ 과 결합하여 $\mathrm{VOT}$ 를 측정한 결과에서도 연구개음의 $\mathrm{VOT}$ 가 양순음과 치조음에 비해서 유의하게 길었다. 마비말장애의 VOT에서도 연령과 관계없이 양순음과 치조음에 비해 연구개음의 VOT가 가장 길게 측정되었다(Ann, 2002; Lee, 2013). 말장애 유무, 연령에 상관없이 조음위치에 따른 VOT의 일관된 특성에 대해서 몇명의 연구자들은 연구개음의 조음운동과 기류역학적인 측면에 서 설명하고 있다. Bóna (2014)는 연구개음의 VOT가 다른 조음위 치의 VOT에 비해서 길게 나타난 것에 대해서 조음위치에 따라서 말산출시에 필요한 압력의 차이로 설명하였다. 즉, 모든 연령대에서 말을 산출할 때 조음위치에 따라서 필요한 성문하압이 다르며, 기 류역학적으로 양순음과 치조음에 비해 연구개음을 산출할 때 더 많은 성문하압이 요구되어 VOT가 더 길어지는 것이다(Cho \& Ladefoged, 1999). 또한, 연구개음의 VOT가 긴 것은 연구개음 산출 시의 조음 움직임과 조음 면적의 영향으로도 볼 수 있는데, 양순음 과 치조음에 비해서 연구개음의 조음 움직임과 조음 면적이 큰 특 징이 VOT를 길어지게 한 것으로도 볼 수 있다(Cho, Jun, \& Ladefoged, 2002).

본 연구에서는 파열음의 발성유형에 따라서 VOT에 유의한 차 이가 있었으며, 격음의 VOT가 평음과 경음에 비해서 유의하게 길 었다. 선행연구(Broersma, 2010; Lee, Ko, \& Kim, 2011; Park et al., 2006; Pyo \& Choi, 1996; Yoo \& Kim, 2015)에서 연령, 장애군, 화자 의 언어와 상관없이 격음의 VOT가 평음과 경음에 비해서 길게 나 타나고 있다. Pyo와 Choi (1996)가 20-30대 한국인 화자 $(\mathrm{N}=30)$ 를 대상으로 양순 파열음(/ㅂ/,/삐/, /프/)을 모음///와 결합하여, 음절 ('CV', 'VCV')별로 VOT를 측정한 결과, 격음의 VOT가 평음과 경 음에 비해 길게 측정되었다. 한국 여성을 대상으로 후행하는 모음 을 $/ \mathrm{i} /, / \mathrm{u} /, / \varepsilon /$ 로 한 CV음절에서 VOT를 측정한 연구결과에서도 격 음의 VOT가 가장 길게 측정되었다(Broersma, 2010). 청년과 노인 을 대상으로 후행하는 모음을 / / /, / / / / T/로 달리하여, CVC음절 의 VOT를 측정한 Yoo와 Kim (2015)의 연구에서도 청년과 노인 모 두 평음과 경음에 비해 격음의 VOT가 길게 측정되었다. Cho와 Ladefoged (1999)는 언어권에 따른 VOT 특성을 살펴보기 위해서 18 개 언어의 치경음과 치조음의 VOT를 비교하였으며, 그 결과, 격 음의 VOT가 평음과 경음에 비해 유의하게 길었다.

본 연구와 선행연구 결과에서 화자의 사용 언어와 연령대에 무 관하게 일반인을 대상으로 한 VOT 연구 외에도 말장애 집단을 대 상으로 한 VOT 연구에서도 격음의 VOT가 평음과 경음에 비해 길 게 나타났다(Lee et al., 2011; Park et al., 2006). 이러한 현상은 격음 이 평음과 경음에 비해서 산출시에 성대폭(maximum opening of the vocal folds)이 커서 성대 진동을 위한 시간이 더 길게 소요되기 때문에 나타난 현상으로 설명할 수 있다(Ladefoged \& Johnson, 2011). 그리고 평음과 경음에 비해서 격음 산출시에 더 많은 성문하 압을 필요로 하는 것도 격음의 VOT에 영향을 미쳤을 것으로 사료 된다(Cho et al., 2002). 또한, 본 연구에서 기능적 조음음운장애 아 동이 연구개음의 경음과 격음에서 일반 아동에 비해 VOT가 짧게 측정되었으며, 이는 아동의 말소리 발달과 관련이 있다고 생각된다. 일반 아동의 말소리 발달은 파열음 중 연구개음의 습득이 가장 늦 고, 발성유형 중 격음의 발달이 늦게 이루어진다(Kim \& Pae, 2005). 조음음운장애 아동의 경우, 일반 아동에 비해 연구개음의 말소리 발달이 완전 습득과 안정화가 늦은 시기에 이루어지므로, 일반 아 동에 비해서 연구개 격음과 경음에서 더 짧은 $\mathrm{VOT}$ 가 측정된 것으 로 생각된다.

본 연구에서는 기능적 조음음운장애 아동의 파열음의 조음위 치와 발성유형에 따른 VOT의 변화가 일반 아동과 동일한 양상을 보였으며, 기능적 조음음운장애 아동의 말 운동 타이밍 통제능력 은 파열음 산출 측면에서는 정상적으로 발달하고 있었다. 이러한 결과는 기능적 조음음운장애 아동의 말소리 문제는 상후두 기관 의 운동 조절 결함보다는 다른 조음기관의 운동 조절, 말 운동통제 보상능력, 말 운동 프로그래밍 능력 등의 저하로 나타날 가능성이 더 크다는 것을 시사한다. 본 연구에서는 취학 전 기능적 조음음운 장애 아동만을 대상으로 하였기 때문에 다양한 연령대의 기능적 조음음운장애 아동의 VOT 특성에 대해서 일반화하기에 어려움 이 있으며, 무의미 문맥에서 파열음의 VOT만을 측정하였기 때문 에 다양한 문맥과 다른 말소리에서의 말 운동통제 능력까지 확대 해석하기 어렵다. 그러므로 향후 연구에서는 기능적 조음음운장 애 아동에게 다양한 문맥에서 VOT를 측정하고, 모음길이, 폐쇄구 간 등의 다양한 음향학적 변수를 측정하여 기능적 조음음운장애 아동의 말 운동통제 능력과 산출 특성을 파악하고자 하는 노력을 할 필요가 있겠다.

\section{REFERENCES}

Ann, E. J. (2002). Comparison of temporal aspects in $V C_{\text {plosive }} V$ context between the normal and spastic cerebral palsy children (Master's thesis). Ewha Womans University, Seoul, Korea.

Auzou, P., Ozsancak, C., Morris, R. J., Jan, M., Eustache, F., \& Hannequin, D. (2000). Voice onset time in aphasia, apraxia of speech and dysarthria: a review. Clinical Linguistics \& Phonetics, 14, 131-150.

Bauman-Waengler, J. (2012). Articulatory and phonological impairments: a 
clinical focus (4th ed.). Boston, MA: Pearson.

Bernthal, J. E., Bankson, N. W., \& Flipsen, P. (2012). Articulation and phonological disorders: speech sound disorders in children (7th ed.). Boston, MA: Pearson.

Bóna, J. (2014). Voice onset time and speakers' age: data from Hungarian. Clinical Linguistics \& Phonetics, 28, 366-372.

Broersma, M. (2010). Korean lenis, fortis, and aspirated stops: effect of place of articulation on acoustic realization. Proceedings of the 11th Annual Conference of the International Speech Communication Association (Interspeech 2010), Makuhari, Japan, 941-944.

Cho, T., \& Ladefoged, P. (1999). Variation and universals in VOT: evidence from 18 languages. Journal of Phonetics, 27, 207-229.

Cho, T., Jun, S. A., \& Ladefoged, P. (2002). Acoustic and aerodynamic correlates of Korean stops and fricatives. Journal of Phonetics, 30, 193-228.

Cohen, W., \& Waters, D. (1999). Measuring speech motor skills in normally developing and phonologically disordered pre-school children. Proceedings of the 14th International Congress of Phonetic Sciences, San Francisco, CA, 789-792.

Fischer, E., \& Goberman, A. M. (2010). Voice onset time in Parkinson disease. Journal of Communication Disorders, 43, 21-34.

Grigos, M. I., Saxman, J. H., \& Gordon, A. M. (2005). Speech motor development during acquisition of the voicing contrast. Journal of Speech, Language, and Hearing Research, 48, 739-752.

Ha, J. W. (2000). Diadochokinetic rate and variability in children with normal and disordered articulation (Master's thesis). Ewha Womans University, Seoul, Korea.

Harel, B. T., Cannizzaro, M. S., Cohen, H., Reilly, N., \& Snyder, P. J. (2004). Acoustic characteristics of Parkinsonian speech: a potential biomarker of early disease progression and treatment. Journal of Neurolinguistics, 17, 439-453.

Hong, H. K., Kim, M. J., Yoo, J., Park, H. T., \& Hong, K. H. (2012). Acoustic characteristics of stop consonant production in the motor speech disorders. Journal of the Korean Society of Laryngology, Phoniatrics and Logopedics, 23, 33-42.

Hong, J., Kang, Y., \& Kim, J. (2015). Comparison of acoustic characteristics of vowel and stops in 3, 4 year-old normal hearing children according to parents' deafness: preliminary study. Journal of the Korean Society of Speech Sciences, 7, 67-77.

Hong, S. M., \& Sim, H. S. (2001). Comparison of articulation ability according to the speaking rate and length of sentences in 4-year-old children with and without articulation disorders. Korean Journal of Communication Disorders, 16, 324-334.

Jeong, J. O., Kim, D. Y., Sim, H. S., \& Park, E. S. (2011). The maximum phonation time and temporal aspects in Korean stops in children with spastic cerebral palsy. Journal of the Korean Society of Speech Sciences, 3, 135-143.

Kang, Y., Kim, Y. D., Ban, J. C., \& Seong, C. J. (2009). A comparison of the voice differences of patients with idiopathic Parkinson's disease and a normal-aging group. Journal of the Korean Society of Speech Sciences, 1, 99-107.

Kent, R. D., \& Lass, N. (1976). Models of speech production. In N. Lass (Ed.), Contemporary issues in experimental phonetics (pp. 79-104). New York: Academic Press.

Kent, R. D., \& Read, C. (2002). The acoustic analysis of speech (2nd ed.). Clifton Park, NY: Delmar, Cengage Learning.

Kim, H. G., Kang, Y. E., \& Kim, Y. H. (2002). An acoustic analysis of speech in patents with nonfluent aphasia. Speech Sciences, 9, 87-97.

Kim, M. J., \& Pae, S. (2005). The percentage of consonants correct and the ages of consonantal acquisition for 'Korean-Test of Articulation for Children (K-TAC)'. Korean Journal of Speech Sciences, 12, 139-149.

Kim, M. J., Pae, S., \& Park, C. I. (2007). Assessment of phonology for children (APAC). Incheon: Human Brain Research \& Consulting Co.

Kim, S. J., \& Shin, J. Y. (2007). Articulatory and phonological disorders. Seoul: Sigma Press.

Kim, Y. T., Hong, G. H., Kim, K. H., Jang, H. S., \& Lee, J. Y. (2009). Receptive \& expressive vocabulary test (REVT). Seoul: Seoul Community Rehabilitation Center.

Ladefoged, P., \& Johnson, K. (2011). A course in phonetics (6th ed.). Boston, MA: Cengage Learning.

Lee, H. H. (2009). Production ability for Korean stops at different speaking rates in cochlear implant children (Master's thesis). Ewha Womans University, Seoul, Korea.

Lee, S. E. (2013). Relationship between the speech intelligibility and the ability of speech motor control by the articulatory severity of dysarthria (Master's thesis). Ewha Womans University, Seoul, Korea.

Lee, S. R., Ko, M. H., \& Kim, H. G. (2011). Voice onset time variations of Korean stop consonants in Aphasic speakers. Annals of Rehabilitation Medicine, 35, 694-700.

Lee, S., \& Iverson, G. K. (2008). Development of stop consonants in Korean. Korean Linguistics, 14, 21-39.

Lee, S., \& Lee, Y. (2015). Effect of age on the voice onset time of Korean stops in VCV contexts. Journal of the Korean Society of Speech Sciences, 7, 37-44. 
Lundeborg, I., Larsson, M., Wiman, S., \& Mcallister, A. M. (2012). Voice onset time in Swedish children and adults. Logopedics Phoniatrics Vocology, 37, 117-122.

Lundeborg, I., Nordin, E., Zeipel-Stjerna, M., \& McAllister, A. (2015). Voice onset time in Swedish children with phonological impairment. Logopedics Phoniatrics Vocology, 40, 149-155.

Morris, R. J. (1989). VOT and dysarthria: a descriptive study. Journal of Communication Disorders, 22, 23-33.

Oh, Y. J., Zhi, M. J., \& Kim, Y. T. (2000). Acoustic comparisons of vowel and plosive productions between the normal and the hearing-impaired children. Speech Sciences, 7, 69-88.

Pae, J., Shin, J., \& Ko, D. H. (1999). Some acoustic aspects of Korean stops in various utterance positions: focusing on their temporal characteristics. Speech Sciences, 5, 139-159.

Park, J., \& Byeon, H. (2015). Variability and duration of voice onset time in childhood apraxia of speech in Korea: results of the spectrum study. International Journal of Bio-Science and Bio-Technology, 7, 67-76.

Park, S., Itoh, M., Hashimoto, R., Kwon, M., Chung, S. J., \& Kim, S. R. (2006). Acoustic analysis of Stop sound production in Korean and Japanese speakers with Parkinson's disease. Korean Journal of Communication Disorders, $11,165-178$.

Pouplier, M., Marin, S., \& Waltl, S. (2014). Voice onset time in consonant cluster errors: can phonetic accommodation differentiate cognitive from motor errors? Journal of Speech, Language, and Hearing Research, 57, 1577 1588 .

Pyo, H. Y., \& Choi, H. S. (1996). The study on intraoral pressure, closure duration and VOT during phonation of Korean bilabial stop consonants. Journal of the Korean Society of Laryngology, Phoniatrics and Logopedics, 7, 50-
55.

Seo, M. K. (2002). An experimental study of voice onset time of Korean stops: correlation with context (Master's thesis). Seoul National University, Seoul, Korea.

Sim, H. S. (2001). Speech motor control approaches to speech disorders: a critique of the literature. Korea Journal of Special Education, 35, 121-142.

Song, Y. K. (2008). Comparison of compensation ability of speech motor control and ability of speech motor programming in children with and without articulation disorders. (Doctoral dissertation). Ewha Womans University, Seoul, Korea.

Towne, R. L. (1994). Effect of mandibular stabilization on the diadochokinetic performance of children with phonological disorder. Journal of Phonetics, 22, 317-332.

Vickie, Y. Y., De Nil, L. F., \& Pang, E. W. (2015). Effects of age, sex and syllable number on voice onset time: evidence from children's voiceless aspirated stops. Language and Speech, 58, 152-167.

Whiteside, S. P., \& Marshall, J. (1998). Voice onset time patterns in 7-, 9- and 11-year old children. Proceedings of the 5th International Conference on Spoken Language Processing, 6, 2687-2690.

Whiteside, S. P., \& Marshall, J. (2001). Developmental trends in voice onset time: some evidence for sex differences. Phonetica, 58, 196-210.

Yoo, H., \& Kim, H. (2015). Acoustic characteristics of stop consonants in normal elderly. Journal of the Korean Society of Speech Sciences, 7, 39-45.

Yu, V. Y., Kadis, D. S., Oh, A., Goshulak, D., Namasivayam, A., Pukonen, M., ... \& Pang, E. W. (2014). Changes in voice onset time and motor speech skills in children following motor speech therapy: evidence from/pa/productions. Clinical Linguistics \& Phonetics, 28, 396-412. 


\section{국문초록}

\section{기능적 조음음운장애 아동의 성대진동시작시간 특성}

박종숙, $\cdot$ 이영미 ${ }^{3}$

'우송대학교 보건복지대학원 언어치료 청각재활학과, ${ }^{2 ㄷ ㅗ ㅇ ㅇ ㅏ ㅇ ㅘ ㅇ ㅜ ㅊ ㅓ ㅇ ㄱ ㅏ ㄱ ㅇ ㅓ ㄴ ㅇ ㅓ ㅅ ㅔ ㄴ ㅌ ㅓ, ~}{ }^{3 ㄷ ㅗ ㅇ ㅁ ㅕ ㅇ ㄷ ㅐ ㅎ ㅏ ㄱ ㄱ ㅛ ~ ㅇ ㅓ ㄴ ㅇ ㅓ ㅊ ㅣ ㄹ ㅛ ㅎ ㅏ ㄱ ㄱ ㅘ ~}$

배경 및 목적: 기능적 조음음운장애 아동의 말 운동통제 능력은 직접적으로 평가하기 힘들며, 말소리 오류의 원인을 파악하는 것은 더 어렵다. 본 연구에서는 파열음의 조음위치와 발성유형에 따른 기능적 조음음운장애 아동과 일반 아동 간의 성대진동시작시간 (voice onset time, VOT)의 차이를 살펴봄으로써, 기능적 조음음운장애 아동의 말 타이밍 조절과 관련된 기제를 살펴보고자 하였다. 방법: 대상자는 대전 및 충남 지역에 거주하고 있는 만 3 세부터 8 세 사이의 기능적 조음음운장애 아동 15 명과 생활연령을 일치시킨 일 반 아동 15 명으로 선정하였으며, 검사 자료는 조음위치와 발성유형을 고려한 총 9 개의 VCV음절을 사용하였다. VOT 측정을 위해서 CSL 프로그램을 이용하였으며, 이때 연구자가 목표 발화를 청취하면서 동시에 스펙트럼 분석 창을 이용하여 VOT를 측정하였다. 결 과: 삼원혼합분산분석을 실시한 결과, 집단에 대한 주효과는 나타나지 않았다. 조음위치에 대한 주효과가 나타나서 $(p<.001)$, 연구개음 의 VOT가 양순음과 치조음에 비해서 유의하게 길었다(all $p<.001)$. 발성유형에 대한 주효과도 유의하여 $(p<.001)$, 격음의 VOT가 평음 과 경음에 비해서 유의하게 길었다(all $p<.001)$. 논의 및 결론: 이러한 결과는 기능적 조음음운장애 아동의 파열음 산출에 대한 후두 와 구강 간의 타이밍 능력은 일반 아동과 비슷한 양상으로 발달한 것을 시사한다.

핵심어: 성대진동시작시간, 기능적 조음음운장애, 아동, 조음위치, 발성유형

\section{참고문헌}

강영애, 김용덕, 반재천, 성철재(2009). 파킨슨병 환자와 정상 노인의 음성비교. 말소리와 음성과학, 1,99-107. 김민정, 배소영(2005). ‘아동용 조음검사를 이용한 연령별 자음정확도와 우리말 자음의 습득연령·음성과학, 12, 139-149.

김민정, 배소영, 박창일(2007). 아동용발음평가(APAC). 인천: 휴브알앤씨.

김수진, 신지영(2007). 조음음운장애. 서울: 시그마프레스.

김영태, 홍경훈, 김경희, 장혜성, 이주연(2009). 수용·표현어휘력검사(REVT). 서울: 서울장애인종합복지관.

김현기, 강은영, 김연희(2002). 비 유창성 실어증 환자 말소리의 음향학적 분석. 음성과학, 9, 87-97.

박성혜, 이토 모토노부, 하시모토 리츠오, 권미선, 정선주, 김성렬(2006). 한국과 일본 파킨슨병 화자의 파열음 음향분석. 언어청각장애연구, 11, 165-

178.

배재연, 신지영, 고도흥(1999). 음성환경에 따른 한국어 폐쇄음의 음향적 특성: 시간적 특성을 중심으로. 음성과학, 5, 139-159.

서민경(2002). 한국어 파열음의 VOT에 관한 실험음성학적 연구: 환경에 따른 VOT 변이를 중심으로. 서울대학교대학원 석사학위논문.

송윤경(2008). 조음장애아동과 비장애아동의말운동통제 보상능력 및 말운동프로그래밍 능력 비교. 이화여자대학교대학원 박사학위논문.

심현섭(2001). 말장애 연구의 동향에 관한 고찰: 말 운동 통제모델을 중심으로. 특수교육학연구, 35, 121-142.

안은정(2002). 정상아동과 경직형 뇌성마비아동의 조음시간 특성에 관한 비교연구: 모음-무기경음-모음환경에서. 이화여자대학교대학원 석사학위

논문.

오영자, 지민제, 김영태(2000). 청각장애아동과 건청아동의 모음 및 파열음 산출의 음향음성학적 특성 비교. 음성과학, 7, 69-88.

유현지, 김향희(2015). 일반 노년층파열음의 음향학적 특성. 말소리와 음성과학, 7,39-45.

이상은(2013). 조음중증도에 따른 마비말장애인의 말 운동통제 능력과 말명료도의 상관연구. 이화여자대학교대학원 석사학위논문.

이슬기, 이영미(2015). 연령에 따른 VCV 문맥에서 한국어 페쇄음의 성대진동개시시간. 말소리와 음성과학, 7,37-44.

이현화(2009). 인공와우이식 아동의 발화속도에 따른 파열음 산출의 음향학적 특성. 이화여자대학교대학원 석사학위논문. 
정진옥, 김덕용, 심현섭, 박은숙(2011). 경직형 뇌성마비 아동의 최대 발성지속시간과 파열음 산출 시 조음시간 특성 비교. 말소리와 음성과학, 3, 135143.

표화영, 최홍식(1996). 한국어 양순 파열음 발음시 구강내압과 폐쇄기, VOT에 대한 연구. 대한후두음성언어의학회지, 7,50-55.

하지완(2000). 기능적 조음장애아동과 정상아동의 교대운동속도 및 가변성 비교. 이화여자대학교대학원 석사학위논문.

홍새미, 심현섭(2011). 4세 조음장애아동과 일반아동의 말속도와 문장길이에 따른 조음능력 비교. 언어청각장애연구, 16, 324-334.

홍지숙, 강영애, 김재옥(2015). 부모의 청각장애 유무에 따른 3, 4세 건청 자녀의 모음 및 파열음 조음의 음향음성학적 특성 비교: 예비 연구. 말소리와 음성과학, 7, 67-77.

홍희정, 김문준, 윤진, 박희택, 홍기환(2012). 운동성 조음장애에서 폐쇄자음 발성의 음향학적 특성. 대한후두음성언어의학회지, 23, 33-42. 